\title{
Pengaruh Inflasi dan Kinerja Keuangan Perusahaan terhadap Pembiayaan pada Bank Umum Syariah (Tahun 2015-2018)
}

\author{
Trisnia Widuri ${ }^{1}$, Nuraidya Fajariah ${ }^{2}$ \\ Prodi Manajemen Fakultas Ekonomi Universitas Islam Kadiri \\ trisniawiduri@ uniska-kediri.ac.id ${ }^{1}$, nuraidyafajariyah@ uniska-kediri.ac.id ${ }^{2}$
}

\begin{abstract}
This study aims to determine the effect of several variables both monetary and performance variables on sharia financing in Islamic Commercial Banks in Indonesia. The data used is the Time Series data from January 2015 to July 2018, sourced from the Islamic Banking Statistics data. To analyze the effect of independent variables on the dependent variable, the author uses the Multiple Linear Regression method. The results showed that the inflation variable as a monetary variable had a significant negative effect on Islamic finance by Islamic Commercial Banks, the company performance variable, FDR and NPL had a significant negative effect on Islamic finance while ROA and CAR had a non-significant effect on Islamic finance.

Keywords: Sharia financing, Inflation, Finance to Deposit Ratio, Non Performing Financing, Return On Assets
\end{abstract}

Abstrak
Penelitian ini bertujuan untuk mengetahui pengaruh beberapa variable baik
variable moneter maupun variable kinerja terhadap pembiayan syariah pada Bank Umum
Syariah di Indonesia. Data yang digunakan adalah data Time Series dari Januari 2015
hingga Juli 2018, yang bersumber dari data Statistik Perbankan Syariah. Untuk
menganalisa pengaruh variable bebas terhadap variable terikat, penulis menggunakan
metode Regresi Linier Berganda. Hasil penelitian menunjukkan bahwa variable Inflasi
sebagai variable moneter berpengaruh negative signifikan terhadap pembiayaan syariah
oleh Bank Umum Syariah, variable kinerja perusahaan yaitu FDR dan NPL berpengaruh
negative signifikan terhadap pembiayaan syariah sedangkan ROA dan CAR mempunyai
pengaruh yang tidak signifikan terhadap pembiayaan syariah.
Kata kunci : Pembiayan Syariah, Inflasi, Finance to Deposit Ratio, Non Performing
Financing, Return On Assets
$\begin{aligned} \text { Permalink/DOI } \quad \text { http://dx.doi.org/10.32503/jmk.v4i2.486 } \\
\text { Cara Mengutip } \quad \begin{array}{l}\text { Widuri, Trisnia., Fajariah, Nuraidya. (2019). Pengaruh Inflasi } \\
\text { dan Kinerja Keuangan Perusahaan terhadap Pembiayaan pada }\end{array} \\
\text { Bank Umum Syariah (Tahun 2015-2018). JMK (Jurnal } \\
\text { Manajemen dan Kewirausahaan), } 4 \text { (2), 136-145 doi: } \\
\text { http://dx.doi.org/10.32503/jmk.v4i2.486 } \\
\text { Artikel diterima 6 April 2019; direvisi 12 April 2019; disetujui } \\
\text { 20 April 2019 }\end{aligned}$
\begin{tabular}{c} 
Sejarah Artikel \\
\hline
\end{tabular}

Alamat korespondensi :

Jl. Sersan Suharmaji No.38

Universitas Islam Kadiri

Kediri, Jawa Timur 


\section{Pendahuluan}

Keuangan Syariah telah berkembang selama lebih dari dua dekade, sejak beroperasinya Bank Muamalat sebagai bank syariah pertama di Indonesia. Sesuai dengan UU Nomor 21 Tahun 2008 tentang Perbankan Syariah, lembaga keuangan Syariah berhak memberikan layanan keuangan pada nasabah dengan berbagai produk perbankan. Hal ini tentu saja akan membuka peluang lebih lebar bagi perbankan syariah untuk menjadi pilihan utama bagi masyarakat. Perkembangan keuangan syariah membuahkan banyak prestasi. Terbukti dengan banyaknya produk dan layanan hingga berkembangnya infrastruktur yang mendukung keuangan syariah.

Menurut Otoritas Jasa Keuangan, market share keuangan syariah masih dibawah 5\%. Hal ini masih belum dapat mengimbangi pertumbuhan keuangan konfensional. Hal ini menunjukkan bahwa keuangan syariah masih perlu terus dikembangkan sehingga dapat mengimbangi pertumbuhan keuangan konvensional.

Sebagai lembaga perbankan, tugas Bank Umum Syariah adalah menghimpun dan menyalurkan dana dari dan kepada masyarakat. Selain tabungan dan deposito, bank Umum syariah juga mempunyai produk berupa pembiayaan syariah. Pembiayaan yang dilakukan dapat berupa sewa guna usaha (Leasing), anjak piutang (factoring), usaha kartu kredit, pembiayaan konsumen (Soemitra, 2015:383)

Ada beberapa keuntungan menggunakan layanan pembiayaan syariah. Selain akad yang jelas, transparansi dalam perjanjian pembiayaan, system yang digunakan dalam pembiayaan syariah juga menggunakan system kekeluargaan serta adanya fasilitas mengangsur sambil berzakat sehingga nasabah menjadi lebih tenang.

Tinggi rendahnya pembiayaan lembaga keuangan, baik syariah maupun konfensional dipengaruhi oleh beberapa hal, antara lain kepercayaan masyarakat akan kinerja perusahaan dalam melakukan pembiayaan, balas jasa yang diterima oleh nasabah hingga berbagai variable makro.

Masyarakat semakin kritis terhadap kinerja perusahaan, perusahaan dengan kinerja yang baik akan mendapatkan kepercayaan dari masyarakat. Fluktuasi keadaan ekonomi secara agregat juga sangat berpengaruh terhadap dinamika kegiatan keuangan oleh lembaga keuangan. Ditengah ketidak pastian ekonomi, lembaga keuangan syariah menjadi pilihan yang membawa keuntungan yang adil bagi nasabah dan juga bagi lembaga.

Pada tahun 2016, total pembiayaan yang disalurkan bank maupun unit usaha syariah mencapai Rp. 203,72 triliun. Akad yang paling banyak diminati adalah murabahah (61\%), musyarakah $(31,7 \%)$ dan mudharabah $(7,29 \%)$. Jumlah itu tumbuh sekira , $11 \%$ dari tahun 2015.

Dana pihak ketiga yang dihimpun oleh Bank Umum Syariah maupun Unit Usaha Syariah juga mengalami kenaikan. Per Oktober 2017, DPK yang dapat di himpun adalah sebesar Rp. 325 triliun, yang di dominasi oleh deposito sebanyak 60,30\%.

Hal tersebut diatas menandakan geliat transakasi keuangan syariah yang semakin dinamis, dana yang terhimpun cukup besar dan permintaan akan pembiayaan syariah pun semakin meningkat.

Dari uraian diatas mendorong 
penulis untuk melakukan penelitian dengan judul pengaruh inflasi dan kinerja perusahaan terhadap pembiayaan bank umum syariah periode tahun 2015-2018.

\section{Tinjauan Pustaka}

\section{Pembiayaan}

Menurut Soemitra (2015: 383), pembiayaan syariah adalah pembiayaan berdasarkan prinsip syariah yaitu pembiayaan berdasarkan persetujuan atau kesepakatan antara perusahaan pembiayaan dengan pihak lain yang mewajibkan pihak yang dibiayai untuk mengembalikan pembiayaan tersebut dalam jangka waktu tertentu dan dengan balas jasa tertentu.

Adapun jenis kegiatan usaha yang dilakukan meliputi, usaha leasing berdasarkan akad ijarah dan ijarah Muntahiyah Bittamlik, anjak piutang dilakukan berdasarkan akad Wakalah bil Ujrah, Pembiayaan Konsumen dilakukan dengan akad Murabahah, salam dan istisna serta usaha Kartu Plastik Syariah dilakukan dengan akad kafalah, qardh dan ijarah.

Menurut Muhammad (2002:70), beberapa prinsip dalam pembiayaan syariah antara lain:

\section{Prinsip keadilan dimana pembiayaan harus menguntungkan bagi pihak penyedia dana dan pengguna}

2. Prinsip kepercayaan dimana merupakan dasar kesepakatan antara kedua belah pihak.

Menurut Warjiyo dalam Istiani (2017), menyatakan bahwa pertumbuhan kredit dipengaruhi oleh penawaran kredit perbankan, persepsi bank terhadap usaha kreditor, dari kondisi perbankan pada saat itu seperti permodalan, kredit macet maupun profitabilitas nya.
Selain kondisi dalam diri perusahaan, variable makro kerap kali membawa pengaruh terhadap pertumbuhan kredit. Kenaikan tingkat inflasi akan menyebabkan jumlah uang yang beredar di masyarakat semakin tinggi. Untuk itu BI akan menaikkan suku bunga dengan tujuan menekan jumlah uang yang beredar di masyarakat. Sehingga tingginya tingkat inflasi akan menurunkan permintaan kredit karena tingkat suku bunga kredit yang semakin tinggi.

Di sisi lain, kondisi perekonomian yang kurang stabil menyebabkan kebutuhan dana meningkat. Pembiayaan syariah sebagai subtitusi atas pembiayaan konvensional akan mengalami peningkatan permintaan kredit. Ketika bank konvensional menaikkan suku bunga kredit sebagai akibat dari kenaikan inflasi, masyarakat akan memilih pembiayaan syariah. Namun, pihak bank Umum Syariah juga akan meningkatkan kehati-hatiannya dalam mencairkan pembiayaan karena adanya inflasi menyebabkan resiko pembiayaan semakin besar.

Telah banyak penelitian yang mengangkat tema pembiayaan syariah. Penelitian yang dilakukan oleh Lita Istiani(2017) dengan judul "Pengaruh Dana Pihak Ketiga dan inflasi terhadap alokasi Pembiayaan Usaha Kecil dan Menengan (Study pada Perbankan Syariah di Indonesia Tahun 2008-2013)" menyimpulkan bahwa DPK berpengaruh pada alokasi pembiayaan UMKM karena semakin tinggi dana yang dihimpun maka semakin besar dana yang dapat di alokasikan untuk pembiayaan. Variable inflasi tidah berpengaruh secara signifikan. Hal itu dikarenakan semakin tinggi inflasi, masyarakat semakin membutuhkan dana untuk usahanya meskipun jumlahnya tidak 
terlalu besar.

Penelitian yang dilakukan oleh Deby Fitri (2018) dengan judul "Analisa Faktor Faktor yang mempengaruhi Pembiayaan pada Bank BNI Syariah Periode 20102017" menyimpulkan bahwa dari berbagai rasio yang yang menggambarkan kinerja perusahaan, BOPO dan NPF berpengaruh positif dan signifikan sedangkan CAR dan FDR berpengaruh negative dan signifikan

Penelitian lain yang dilakukan oleh Umiyati (2017) dengan judul "Faktor yang Mempengaruhi Pembiayaan pada Bank Umum Devisa di Indonesia" menyimpulkan bahwa ROA, NPF dan Inflasi tidak signifikan mempengaruhi pembiayaan Bank Umum Syariah, sedangkan FDR dan DKP mempunyai pengaruh yang signifikan terhadap pembiayaan Bank Umum Syariah di Indonesia.

\section{Inflasi}

Inflasi merupakan kenaikan harga yang terus menerus. Inflasi sering kali di ikuti dengan melemahnya daya beli dan menurunnya nilai riil mata uang suatu negara.

Menurut Sadono Sukirno (2013:263), dampak inflasi pada perekonomian antara lain:

1. Inflasi menimbulkan dampak negative pada distribusi pendapatan.

2. Inflasi yang tinggi berdampak pada pertumbuhan ekonomi.

Kenaikan harga yang terus menerus menyebabkan jumlah uang yang beredar dimasyarakat semakin tinggi. Untuk mengatasinya BI akan mengambil kebijakan moneter yaitu dengan menaikkan tingkat suku bunga untuk menekan jumlah uang yang beredar dimasyarakat.

\section{Kinerja Keuangan Perusahaan}

Menurut Jumingan (2014:239), kinerja keuangan adalah gambaran kondisi keuangan perusahaan pada periode tertentu menyangkut aspek penghimpunan dana dan penyaluran dana yang biasanya di ukur dari likuiditas, profitabilitas dan kecukupan modal,

Rasio likuiditas perbankan syariah di proksikan oleh FDR (Financing to Deposit Ratio). FDR merupakan perbandingan jumlah pembiayaan kredit yang diberikan dengan simpanan masyarakat (Kuncoro, 2002). Sesuai dengan ketentuan Bank Indonesia, Bank Syariah yang sehat adalah apabila FDR nya antara 85\% $110 \%$. Semakin besar dana yang disalurkan pada masyarakat berupa kredit akan memberikan kesempatan kepada Bank untuk mendapatkan keuntungan, meskipun hal ini juga mengandung resiko kredit yang besar pula.

Dalam kinerja pembiayaan sering kali Bank harus mempunyai kemampuan dalam mengelola kredit yang di salurkan. Menurut Luh Gede Meydianawathi (2007:138), NPL atau NPF adalah kemampuan bank dalam mengumpulkan kembali kredit yang dibayarkan oleh bank.

Rasio Profitabilitas adalah kemampuan perusahaan dalam menghasilkan laba atau profit. ROA atau Return on Aset merupakan suatu rasio yang digunakan untuk mengukur kemampuan perusahaan dalam menghasilkan keuntungan dengan memanfaatkan asset nya.

Rasio kecukupan modal pada perbankan di proksikan dengan CAR. CAR atau Capital Adequacy Ratio adalah rasio kecukupan modal yang berfungsi menampung kerugian yang mungkin dihadapi oleh bank. Semakin tinggi CAR, semakin baik 
kemampuan bank tersebut untuk membiayai kegiatan operasionalnya (Budisantoso,2006)

\section{Metodologi Penelitian}

Penelitian ini termasuk dalam penelitian asosiatif yaitu penelitian yang bertujuan untuk menguji hubungan dua variable atau lebih (Supriyanto, 2013:7). Penelitian ini bertujuan untuk menguji pengaruh Inflasi, CAR, FDR, ROA dan NPF terhadap Pembiayan pada Bank Umum Syariah.

Populasi dari penelitian ini adalah laporan statistik seluruh Bank Umum Syariah di Indonesia. Teknik pengambilan sampel menggunakan Non Probability sampling dengan metode Purposive sampling yaitu teknik penentuan sampel dengan pertimbangan tertentu (Supriyanto, 2013:37). Adapun criteria yang diambil adalah kelengkapan data.

Data yang diambil adalah data sekunder runtut waktu (Time Series) bulanan dari bulan Januari 2015 sampai dengan bulan Juli 2018 sebanyak 43 data observasi.

Data diperoleh dari Statistik Perbankan Syariah yang di publikasikan oleh Otoritas Jasa Keuangan pada website nya yaitu www.ojk.go.id .

Teknik analisa yang dipakai adalah analisa regresi linier berganda. Analisa regresi merupakan analisa ketergantungan dari satu atau lebih variable bebas terhadap satu variable tergantung (Suliyanto, 2011:37). Tujuan analisa regresi adalah untuk memprediksi nilai populasi berdasarkan nilai variable bebasnya. Bentuk umum Regresi Linier Berganda adalah :

$$
\begin{aligned}
& \mathrm{Y}=\mathrm{a}+\mathrm{b} 1 \mathrm{X} 1+\mathrm{b} 2 \mathrm{X} 2+\mathrm{b} 3 \times 3+\mathrm{b} 4 \mathrm{X} 4 \\
& +\mathrm{b} 5 \mathrm{X} 5
\end{aligned}
$$

Dimana:

Y : Pembiayaan Bank Umum Syariah a : konstanta

$\mathrm{X} 1$ : Inflasi

$\mathrm{X} 2$ : FDR

$\mathrm{X} 3: \mathrm{NPF}$

$\mathrm{X} 4: \mathrm{ROA}$

$\mathrm{X} 5$ : CAR

b1,b2,b3,b4,b5 : koefisien regresi

Uji yang dilakukan antara lain:

1. Uji Regresi Linier Berganda

2. Uji penyimpangan Asumsi Klasik,. Uji tersebut dilakukan untuk mengetahui apakah model regresi yang digunakan telah BLUE.

Terdiri dari uji multikolinieritas, uji heterokedastisitas dan uji otokolerasi

3. Uji hipotesis, untuk menguji kebenaran hipotesis.

Terdiri dari Uji parsial, uji simultan dan koefisien determinasi.

\section{Hasil}

\section{Uji Regresi Linier Berganda}

Dari hasil analisa data didapat nilai sebagai berikut :

Table 1.Nilai koefisien

\begin{tabular}{|l|l|}
\hline \multicolumn{1}{|c|}{ Model } & \multicolumn{1}{c|}{ Nilai koefisien } \\
\hline (Constant) & 488714.877 \\
\hline X1 inflasi & -1298.095 \\
\hline X2 FDR & -2992.746 \\
\hline X3 NPF & -9761.616 \\
\hline X4 ROA & -5980.073 \\
\hline X5 CAR & -385.112 \\
\hline \multicolumn{2}{|l}{ Surber }
\end{tabular}

Sumber: Data diolah (2019) 
Dari tabel diatas didapatkan persamaan regresinya adalah :

\section{$Y=488714.877-1298.095 X 1-$ 2992.746X2 - 9761.616X3 - 5980.073X4 -385.112X5}

Persamaan tersebut dapat di baca :

a. Nilai konstanta 488714.877, artinya bila variable lain dianggap konstan, maka pembiayaan Bank Umum Syariah sebesar 488714.877 satuan.

b. Nilai koefisien Inflasi sebesar 1298.095, artinya bila Inflasi naik sebesar 1 satuan maka pembiayaan akan turun sebesar 1298.095 satuan.

c. Nilai koefisien FDR sebesar 2992.746, artinya bila Rasio FDR naik 1 satuan maka pembiayaan akan turun sebesar 2992.746 satuan.

d. Nilai koefisien NPF sebesar 9761.616, artinya jika nilai NPF naik sebesar 1 satuan maka pembiayaan akan turun sebesar 9761.616 satuan.

e. Nilai Koefisien ROA sebesar 5980.073, artinya jika ROA naik sebesar 1 satuan maka pembiayaan akan turun sebesar 5980.073 satuan.

f. Nilai koefisien CAR sebesar 385.112, artinya jika CAR naik sebesar 1 satuan maka pembiayaan akan turun sebesar 385.112 satuan.

\section{Uji Asumsi Klasik}

Uji asumsi klasik adalah suatu alat untuk menguji apakah model regresi linier yang digunakan telah valid sebagai alat peramalam. Apabila telah terpenuhi semua ujinya maka model regresi tersebut dikatakan BLUE atau Best Linier Unbias Estimation.
Pada penelitian terdapat 3 uji untuk menguji apakah model regresi yang digunakan telah BLUE, yaitu uji multikolinieritas, uji heterokedastisitas dan uji otokolerasi.

a. Uji Multikolinieritas

Suatu model dikatakan mempunyai multikolinieritas artinya terdapat hubungan yang kuat antar variable bebas, sehingga model menghasilkan peramalan yang bias. Ditandai dengan koefisien determinasi yang tinggi, uji $\mathrm{t}$ dan uji $\mathrm{F}$ yang hasilnya sangat kecil (Suliyanto, 2011:81). Uji yang dilakukan untuk mendeteksi adanya multikolinieritas adalah TOL (Tolerance) dan VIF (Variance Inflation Factor). Dengan melihat nilai VIF nya jika >10, maka tidak terjadi gejala multikolinieritas.

Tabel 2. Nilai TOL dan VIF

\begin{tabular}{|l|l|l|}
\hline Variabel & TOL & \multicolumn{1}{|c|}{ VIF } \\
\hline Inflasi & 0.582 & 1.718 \\
\hline FDR & 0.186 & 5.374 \\
\hline NPF & 0.490 & 2.042 \\
\hline ROA & 0.503 & 1.987 \\
\hline CAR & 0.178 & 5.610 \\
\hline \multicolumn{2}{|l|}{ Sumber: Data diolah (2019) } \\
\hline
\end{tabular}

Dari table diatas nilai VIF tidak ada yang melebihi 10 , sehingga dapat dikatakan model tidak terjadi gejala multikolinieritas.

b. Uji Heterokedastisitas

Menurut Suliyanto (2011: 95),uji ini digunakan untuk mengetahui apakah ada perbedaan varian variable dalam model. Yang diharapkan dalam model terdapat 
nilai varian variable yang sama (homokedastisitas). Untuk pengujiannya dapat dilakukan dengan berbagai macam metode salah satunya dengan metode analisa Grafik atau Plot.

Scatterplot

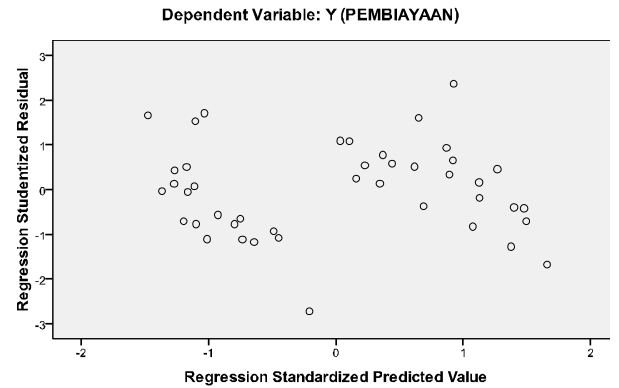

Gambar 2. Scater Plot

Sumber: Data diolah (2019)

Dari scater plot diatas diketahui bahwa data menyebar, tidak membentuk suatu pola sehingga dapat dikatakan bahwa model regresi tidak terjadi gejala heterokedastisitas.

\section{c. Uji Otokolerasi}

Uji ini bertujuan untuk mengetahui apakah ada korelasi antara anggota serangkaian data observasi yang diuraikan menurut waktu (time Series) atau ruang (cross section) (Suliyanto, 2011:125). Untuk mengetahui ada tidaknya gejala otokolerasi dapat dilakukan dengan Metode Durbin Watson.

Dari hasil analisa data didapat nilai Durbin Watson sebesar 1,611. Jika nilai $\mathrm{dL}=1,206$ dan $\mathrm{dU}=1,550$, sehingga nilai $4-\mathrm{dU}=$ $4-1,550=2,450$ sedangkan $4-d L$ $=4-1,206=2,794$. Nilai Durbin Watson $(1,611)$ terletak diantara dU dengan 4-dU sehingga dapat disimpulkan model tidak terjadi gejala otokolerasi.

\section{Uji Hipotesis}

a. Uji t

Untuk menguji apakah variable bebas secara parsial mempunyai pengaruh terhadap variable terikat, maka dilakukan uji t. Dengan tingkat probabilitas 5\%, maka suatu variable dapat dikatakan mempunyai pengaruh signifikan apabila nilai signifikasi t nya $>0,05$.

Table 3. Nilai Sig t Test

\begin{tabular}{|l|l|}
\hline variabel & Sig t \\
\hline X1 Inflasi & 0.038 \\
\hline X2 FDR & 0.000 \\
\hline X3 NPF & 0.000 \\
\hline X4 ROA & 0.071 \\
\hline X5 CAR & 0.692 \\
\hline Sumber: Data diolah (2019)
\end{tabular}

Dari table di atas dapat diketahui bahwa variable Inflasi, FDR dan NPF mempunyai pengaruh yang signifikan terhadap pembiayaan.

Sedangkan variable ROA dan variable CAR mempunyai pengaruh yang tidak signifikan terhadap pembiayaan.

b. Uji F

Untuk menguji apakah variable $\mathrm{X} 1, \mathrm{X} 2, \mathrm{X} 3, \mathrm{X} 4$ dan X5 secara simultan mempunyai pengaruh terhadap pembiayaan Bank Umum Syariah, dapat dilakukan Uji F. Dengan tingkat probabilitas 5\%, maka model dikatakan mempunyai pengaruh yang signifikan apabila nilai signifikasi F nya $>0.05$ 
Table 4. Annova

\begin{tabular}{|l|c|c|}
\hline \multicolumn{1}{|c|}{ Model } & F & Sig F \\
\hline Regretion & 122.354 & 0.000 \\
\hline \multicolumn{3}{|l}{ Sumber: Data diolah (2019) }
\end{tabular}

Dari table diatas nilai Sig $F$ sebesar 0.00>0 0.05 sehingga dapat disimpulkan bahwa secara simultan, model mempunyai pengaruh yang signifikan terhadap pembiayaan Bank Umum Syariah.

c. Koefisien determinasi (Adjust $\mathrm{R}^{2}$ )

Table 5. Model Sumarry

\begin{tabular}{|l|l|l|}
\hline R & \multicolumn{1}{|r|}{$\begin{array}{c}\text { R } \\
\text { Square }\end{array}$} & $\begin{array}{c}\text { Adjust R } \\
\text { Square }\end{array}$ \\
\hline 0.971 & 0.943 & 0.935 \\
\hline
\end{tabular}

Dari table di atas diketahui nilai Adjust R Square sebesar 0.935 yang artinya variable Inflasi, FDR, NPF, ROA dan CAR mempengaruhi Pembiayaan Bank Umum Syariah sebesar 93,5\% dan sisanya yaitu sebesar $6,5 \%$ dipengaruhi oleh variable lain diluar model.

\section{Pembahasan}

Berdasarkan pengujian model Regresi Linier Berganda didapatkan koefisien variable Inflasi sebesar 1298.095 dengan nilai Sig t sebesar 0.038 yang lebih kecil daripada 0.05 . dari sini dapat di interpretasikan bahwa variable Inflasi mempunyai pengaruh negative dan signifikan terhadap Pembiayaan. Hal ini sejalan dengan teori. Bahwa semakin tinggi inflasi maka suku bunga kredit akan semakin tinggi. Meskipun Bank Umum Syariah tidak menggunakan bunga sebagai balan jasanya, namun nilai balas jasa yang ditetapkan juga akan semakin tinggi sejalan dengan menurunnya nilai riil mata uang.

Dari hasil pengujian regresi didapatkan nilai koefisien variable FDR adalah -2992.746, dan nilai Sig t sebesar 0.00 yang artinya FDR mempunyai pengaruh negative dan signifikan terhadap Pembiayaan pada Bank Umum Syariah. Semakin tinggi nilai FDR maka semakin banyak kredit yang dikeluarkan Bank Umum Syariah sehingga resiko kredit juga semakin besar.

Nilai koefisien regresi untuk NPF sebesar -9761.616 dengan tingkat signifikasi t sebesar 0.00 . hal ini dapat diartikan bahwa NPF mempunyai pengaruh negative dan signifikan terhadap pembiayaan Bank Umum Syariah. Ketika nilai NPF naik, maka bank syariah akan meningkatkan prinsip kehati hatian. NPF merupakan suatu rasio yang kenaikan nya menandakan semakin tinggi kredit yang macet dalam pembiayaan Syariah tersebut. Tinggi nya nilai NPF menandakan bahwa pengelola bank kurang berhati hati dalam mencairkan kredit.

Untuk ROA mempunyai nilai koefisien regresi sebesar -5980.073, dengan tingkat signifikasi $\mathrm{t}$ sebesar $0.071>0.05$, sehingga dapat diartikan bahwa ROA mempunyai pengaruh negative dan tidak signifikan terhadap pembiayaan Bank Umum Syariah. Hal ini tidak sejalan dengan teori. Pembiayaan merupakan peluang bagi Bank untuk mendapatkan keuntungan. Hal itu akan terganggu apabila banyak terjadi kredit macet. Yang mana kredit macet tersebut akan menjadi beban bagi perusahaan.

Hal serupa terjadi pada CAR. Dari nilai koefisien sebesar -385.112 dan tingkat signifikasi t sebesar $0.692>$ 0.05, dapat diartikan bahwa CAR 
mempunyai pengaruh negative namun tidak signifikan terhadap pembiayaan Bank Umum Syariah. Penurunan CAR terjadi ketika terjadi kenaikan pembiayaan sehingga dapat diartikan bahwa dana yang disalurkan kepada masyarakat belum dapat dikembalikan seperti semua. Hal ini dapat dilihat dari nilai rasio kecukupan modal yang mempunyai koefisien negative terhadap pembiayaan.

Secara simultan atau bersama sama, ke lima variable yaitu Inflasi, FDR, NPF, ROA dan CAR mempunyai pengaruh yang signifikan terhadap Pembiayaan Bank Umum Syariah dan dengan pengaruh yang cukup tinggi yaitu sebesar $93.5 \%$.

\section{Simpulan}

Dari hasil analisa data dapat disimpulkan bahwa :

1. Inflasi mempunyai pengaruh negative dan signifikan terhadap pembiayaan bank Umum Syariah

2. FDR mempunyai pengaruh negarif dan signifikan terhadap pembiayaan Bank Umum Syariah

3. NPF mempunyai pengaruh negative dan signifikan terhadap pembiayaan Bank Umum Syariah

4. ROA mempunyai pengaruh negative dan tidak signifikan terhadap pembiayaan Bank Umum Syariah

5. CAR mempunyai pengaruh negative dan tidak signifikan terhadap pembiayaan Bank Umum Syariah.

6. Variable Inflasi, FDR, NPF, ROA dan CAR secara simultan signifikan mempengaruhi pembiayaan pada Bank Umum Syariah.

Berdasarkan analisa yang telah dipaparkan dipembahasan, dapat dilihat fenomena yang terjadi berkaitan dengan pembiayaan Bank Umum Syariah. Kemudahan dalam pencairan kredit, kurang hati hatinya manajemen dalam mengelola kredit macet menyebabkan pembiayaan menjadi beban bagi Bank Umum Syariah. Seyogyanya system yang digunakan dalam pembiayaan Syariah lebih di perhatikan lagi dan prinsip kehati hatian dalam pemcairan kredit lebih di tegaskan lagi, sehingga pembiayaan dapat menjadi peluang bagi perbankan Syariah untuk mendapatkan keuntungan dan mengembangkan bisnis.

\section{Daftar Pustaka}

Budisantoso, Totok. 2014. Bank dan Lembaga Keuangan Lain. Jakarta : Salemba Empat

Fitri, Deby. 2018. Analisa Faktor Faktor yang mempengaruhi Pembiayaan pada Bank BNI Syariah Periode 2010-2017. Diunduh dari www.google.com, 5 November 2018.

Istiani, Lita . 2017. Pengaruh Dana Pihak Ketiga dan inflasi terhadap alokasi Pembiayaan Usaha Kecil dan Menengan (Study pada Perbankan Syariah di Indonesia Tahun 2008-2013). Di unduh dari www.google.com, 5 November 2018.

Jumingan. 2014. Analisa laporan Keuangan. Bumi Aksara

Kuncoro, Mudrajat. 2014. Metode Riset untuk Bisnis dan Ekonomi. Jakarta : Erlangga.

Medianawathi, Luh Gedhe. Analisa Perilaku Penawaran Kredit Perbankan kepada Sektor UMKM di Indonesia. Denpasar : Universitas Udayana

Muhamad .2016. Manajemen 
145 JMK (Jurnal Manajemen dan Kewirausahaan) 4 (2) 2019, 136-145

Pembiayaan Bank Syariah. Jakarta : UPP STIM YKPN

Otoritas Jasa Keuangan. Statistik Perbankan Syariah. Laporan terpublikasi. www.ojk.go.id

Sukirno, Sadono. 2010. Makroekonomi : Teori dan Pengantar. Jakarta : Rajawali Pers.

Suliyanto. 2010. Ekonometrika Terapan : Teori dan Aplikasi dengan SPSS. Yogyakarta : Andi Offset.

Sumitra, Andri. 2015. Bank dan Lembaga Keuangan Syariah. Jakarta : Prenadamedia Group.

Supriyanto, Ahmad Sani. 2013. Metodologi Penelitian MSDM. Yogyakarta : UIN Maliki Press.

Umiyati. 2017. Faktor yang Mempengaruhi Pembiayaan pada Bank Umum Devisa di Indonesia. Diunduh dari www.google.com, 5 Novenber 2018.

Undang-undang Republik Indonesia Nomor 21 tahun 2008. Di unduh dari www.google.com 